\title{
A Review on Sustainability Principles of Building: Formulation of a Theoretical Framework
}

\author{
Nor Kalsum Mohd Isa ${ }^{1}$, Zulkiflee Abdul Samad ${ }^{2}$ and Anuar Alias ${ }^{3}$ \\ ${ }^{1}$ Faculty of Human Science, Sultan Idris Education University, Malaysia \\ ${ }^{2,3}$ Faculty of Built Environment, University of Malaya, Malaysia \\ 1'umie772003@yahoo.co.uk, 2ulkiflee1969@um.edu.my, ${ }^{3}$ anuar_a@um.edu.my
}

\begin{abstract}
Sustainable development has received encouraging attention since the Rio Declaration on Environment and Development was signed in 1992 Earth Summit. In Malaysia, the focus on sustainability in building, especially in devising policies has been spelled out in the government policies at national, state and local level. It can be considered that many efforts relating to sustainability in building project have been implemented in the country, however till now sustainability in Malaysian building projects are still remain without proven. It was revealed that most of the current frameworks of sustainability in the country are not equipped to handle sustainable building project. It is often encouraged environmental measure in most cases, yet the rest of measures are less promoted. To response to the issues, this study therefore aims to explore the sustainability principles of building through the review of relevant literatures. Content analysis is used to identify the principles in the sustainability literature relevant to building projects. A theoretical framework of sustainability principles of building was then formulated to be the main outcome of the study. The framework consists of a list of 29 sustainability principles of building to be taken into account throughout the project development process. The findings is very important to be a useful starting point for future study, especially for formulating a clear guide for the development of upcoming sustainable building projects to its actual meaning.
\end{abstract}

Keywords: sustainability principles; sustainable building; construction project

\section{INTRODUCTION}

There is a growing concern about the long-term future, the resources of the planet, the environment and high levels of poverty, which are linked with the spread of disease, social unrest, population growth and environmental degradation (Chaharbaghi \& Wilis, 1999). Although these issues could stem from various causes, unsustainable construction project could be one of them. Zainul Abidin (2010) stated that construction activities will influence the sustainable development from its impact to the output. A building imposes in-use impact to the environment such as energy wastage, waste disposals, greenhouse emission, and soil contamination (Zainul Abidin, 2010). Several arguments also highlighted that building sector is the largest (45\%) sources of greenhouse gas emission around the globe (Edward, 1998; Wu \& Low, 2010).

In a bid to realize sustainability in Malaysian building project, Malaysia have spent many efforts and resources on the industry especially in devising policies as evidenced in Seventh (1996-2000), Eight (2001-2005), Ninth (2006-2010) and Tenth Malaysia Plans (2011-2015). Wider adoption of Green Building Index (GBI) to benchmark energy consumption in the new and existing buildings has also been emphasized (Isa et al, 2014; Md Darus et al, 2009; Zainul Abidin, 2009). However, the tools are often encouraged environmental measure in most cases, yet the rest of measures are less promoted (Isa et al, 2014). The GBI Malaysia rating system is also obviously to focus more on 
environmental aspect of sustainability. Besides, Malaysian stakeholders who are currently involved in building project were claimed to be not fully understood with the concept and principles of sustainability. Lack of exposure towards sustainability (Zainul Abidin, 2009) and a proper sustainable building framework (Isa et al, 2014) has resulted to the lack of Malaysian professional capabilities to consult on sustainability.

Most sustainability-related building standards and methodologies that have been developed worldwide are more focused on evaluating environmental performance of buildings such as LEED (Leadership in Energy and Environmental Design), a method developed in the United State of America with a world wide application, CASBEE (Comprehensive Assessment System for Building Environmental Efficiency), a method developed in Japan, BREEAM (Building Research Establishment Environmental Assessment Method) in the United Kingdom, HQE (High Environmental Quality) developed in France, and GBI Malaysia, an environmental rating system for building, which was developed in 2009 by PAM (Malaysian Institute of Architects) and ACEM (The Association of Consulting Engineers Malaysia). Unfortunately, the standards and methodologies for sustainable building that clearly incorporates the environment, social and economic aspects of sustainability and their interdependencies are rarely found.

The aim of this study was to explore the sustainability principles of building through the review of relevant literatures. By investigating the principles, this research seeks to make a contribution towards formulating a clear guide for the development of successful sustainable building projects in Malaysia in the future.

\section{THE CONCEPT OF SUSTAINABLE BUILDING}

'Sustainability' is not considered as a new concept as it was used since the 1970's (Grevelman \& Kluiwstra, 2010) even though the practice during the time was still largely hold a preservationist philosophy. The concept only had gained global political recognition since it was introduced by the Brundtland Report titled 'Our Common Future' in 1987 at the United Nation Conference on Environment and Development (Lowe \& Zhou, 2003). The report was the first which focuses on global sustainability which explicitly addressed the links between social, economic and environmental dimensions of development and sustainability towards devising a new development model, that of 'sustainable development'. Since then, many progressive world events had taken place to increase the sustainability agendas. Some of the sustainability key documents that have been produced in order to realize the agenda are Agenda 21 (1992), The Rio Declaration on Environment and Development (1992), The United Nations Framework on Climate Change (1992) and its Kyoto Protocol (1997), The Millennium Declaration (2000) and The Johannesburg Plan of Implementation (2002). Added to that, there are quite many Building Performance Assessment Systems (BPASs) have been developed worldwide to measure mainly on the environmental aspect of sustainability in building such as LEED, BREEAM, CASBEE and GBI Malaysia.

The concept of sustainability is a non-rigid doctrine. The term and concept of sustainability are actively redesigned for the specific purpose at any given time and context. In construction industry, a variety of sustainable based concepts are used such as sustainable and green building, sustainable and green construction and sustainable and green project management and so on. The fact shows that the words green and sustainable are often used synonymously and interchangeably. However, according to the Bruntdland Report published in 1987, sustainable means 'meeting the needs of the present generation without compromising the needs of future generations' (WCED, 1987). Due to flexible nature of the concept, many definitions currently exist for the term 'sustainable' and 'sustainable development' which most of them have been extended to be based upon the three 
pillars of 'triple bottom line' concept that developed in 1997 by John Elkington (Edward, 1998; Grevelman \& Kluiwstra, 2010; Larsen, 2009; Magis \& Shinn, 2009; Popea et al., 2004). Summing up the arguments, sustainable building is considered as an approach for the building industry to move towards sustainable development by taking into account environmental, social and economic issues (Akadiri et al, 2012). On the other hand, green building is meant to be a building that exhibits energy efficiency, resource depletion, impact on environment and protection of health and environment (Beatley, 2008; Lutzkendoft \& Lorenz, 2006).

Most published works relating to the concept of sustainable building, however undeniably was influenced by the initial concept of sustainability which are about limited resources and to reduce impact to the natural environment with emphasis on the technical issues such as materials, building components, construction technologies and energy related design concepts (Md Darus et al., 2009; Zainul Abidin, 2009). This concept is seen to be inclined by the Bruntdland's definition in 1987. For instance, Kibert (2005) highlighted that the practice of sustainable building refers to the creation and operation of a healthy built environment based on resource efficiency and ecological design with an emphasis on seven core principles across the building life cycle which are, 1) reducing resource consumption, 2) reusing resources, 3) using recyclable resources, 4) protecting nature, 5) eliminating toxics, 6) applying life cycle costing, and 7) focusing on quality. It was noticed that the definitions are imbalanced which tend to focus more on environmental measure which is regularly called as 'green building' while the other sustainable development measures have been relatively forgotten. Added to that, much attention has been given on green design and green construction rather than on the complete project life cycle (Wu \& Low, 2010). In Malaysia for instance, a survey by Zainul Abidin in 2009 found that most Malaysian developers understand 'sustainable construction' only from the environmental perspective $(88.6 \%)$ and valued social and economic elements as separate entities.

Various techniques and methodologies exist to measure the sustainability principles of building including BPASs. Even though the BPASs are skewed towards green measures, they were developed to assist the delivery of buildings that better suited to their physical settings and that impact positively towards sustainability (Kaatz et al, 2006). Some BPASs only consider very specific aspects of building performance such as energy usage (for example Energy Star), materials used or waste generated during construction or operation. Others try to take a broader view, through a set of design and operational criteria. For commercial building for instance, the two most commonly used criteria are BREEAM and LEED (CBRE, 2009). The development of assessment system for buildings (BPASs) has its origin in the 1990s as this was the year when the first BPAS, the BREEAM was introduced. Following the launch of BREEAM, many other BPASs were developed around the world. Cole (2006) stated that the BREEAM has become the source of many succeeding methods which many of them have similar roots such as LEED (United States), Green Star (Australia) and HK-BEAM (Hong Kong). However, most of them are actually covering a range of schemes for assessing environmental performance of buildings (CBRE, 2009; Cole, 2006; Du Plessis, 2005; Kaatz et. al, 2005; Todd et al, 2001). The BPASs are generally having similar categories such as energy, indoor environmental quality, site and waste management, water, building materials and innovations, even the number of criteria categorized under each category varies. Different systems also often categorized similar criteria under different category. BPASs which address several non-environmental issues such as proper location and accessibility are also relate to the basic environmental concern. Very few BPASs address purely non-environmental issues such as health and safety, creating job for local people, excellent labour practices, economic aspects or others. 
According to Adler et al. (2006) the definition of sustainable building should go far beyond the environmental aspect. In accordance with the three aspects of sustainable development, which are economic, social and environmental, sustainable buildings can benefit human well-being, community, environmental health and life cycle costs. Fortunately, nowadays the significance of the non-technical issues such as economic, social and cultural aspects have been emphasized gradually (DETR, 2000; Zainul Abidin, 2009). This practice is not only to help the environment but also improves economic profitability and relationships with stakeholder groups or in other words, it can be benefited to both; the economic and social aspects. Akadiri et al (2012) and, Hill and Bowen (1997) added that sustainable building is consisting of four principles; social, economic, biophysical and technical. Sustainable building also is about the integration of sustainable development considerations throughout the whole life of building process (Gething \& Bordass, 2006; Yudelson, 2009). The authors conclude the concept and principles of a sustainable building are as discussed in the Findings Section of this paper and graphically presented in Figure 2.

\section{THE BENEFITS OF A SUSTAINABLE BUILDING}

Sustainable buildings impact the environment less during construction, provide healthier place for their occupants and are more cost-efficient over the life cycle than conventional structures (Doyle et al., 2009). To be commercially, socially and environmentally sustainable building, measurable and immeasurable benefits need to be revealed in order to persuade developers and clients to risk new approaches and use the new sustainable technologies. Several authors have found the net benefits of sustainable building as follows:

\section{DIRECT BENEFITS}

\section{Reduce Energy Consumption, Economies in Operational Cost and Fuel Bills either for Owner or Tenant}

According to Choi (2009), capital costs are not high for many green and sustainable building elements and even where upfront costs are more elevated, they can be offset by decreased operational costs. Research shows that sustainable building practices can considerably reduce the built environment's role in energy consumption (CBRE, 2009; Edward, 1998). Depending on the level of improvement, these savings at least exceed $10 \%$ and could be well over $50 \%$ (CBRE, 2009). A survey of ninety-nine sustainable buildings in the United State showed they use an average of $30 \%$ less energy than conventional buildings. Meanwhile, other research in United State also found that energy efficient design able to reduce building energy consumption by as much as $50 \%$ (The Economist, 2004). An example of a successful sustainable building is the head-quarters of NMB in Amsterdam constructed in 1990, built to meet low-energy and high environmental standards, with plenty of user control over the temperature and humidity of working areas. It was reported to have saved more than $£ 300000$ a year in energy costs against a conventional office building of similar size. The energy consumption is one-twelfth that of the bank's former building allowing the owner to calculate that the additional cost of plant and equipment was paid for in three months of occupation. Furthermore, NMB have found that absenteeism is $15 \%$ lower than in the old building adding considerably to the bank's performance. Therefore, it has proved a success in financial and productivity term.

Although initial costs of sustainable construction can be higher than conventional projects, it is widely held that longer-term cost savings in operations and maintenance can help recover those costs. Sustainable buildings are expected to decrease operating costs between 8-9\%, increase total 
building value by about $7.5 \%$ and increase occupancy rates by $3.5 \%$ (USGBC, 2006a; b). More examples of worldwide successful sustainable buildings are shown in Table 1.

\section{Market Advantage and Lower Long-Term Exposure to Environmental or Health Problems}

The evidence record for this is limited, but analysis from the US indicates that the sustainable buildings do attract higher rents than conventional ones and also enjoy higher rates of rental growth (CBRE, 2009). A survey by developer St James' on their Kennet Island sustainable residential scheme in Reading, England revealed that four-fifths of residents would pay up to $£ 3,000$ for each of a select group of green and sustainable features, including solar PV tiles, solar hot water tiles, Powerpipe hot water heat exchangers, grey water recycling and wind turbine. A research by real estate experts in Australia found out that majority of Australian investors are willing to pay more for a Green Star building (Muldavin, 2010). The improved marketability subject of sustainable buildings is the main current competitive advantage which are easier to sell and lease, which reduces vacancy times and hence income losses (McKee, 1998). The buildings also able to fulfill user satisfaction, benefits to health and comfort, increase company image, having commercial advantage for environmental ethics, value for money in long term, adding the sale value of buildings and simpler to re-lease in the future (Edward, 1998; and McKee, 1998).

\section{Greater Productivity of Workforce}

Sustainable buildings also have social impacts on the health and wellbeing of building occupants. Design features that promote sustainability have resulted in lower absenteeism and higher productivity rates among employees. A study conducted after Lockheed Martin completed sustainable engineering and design facility in Sunnyvale, California showed that absenteeism rates dropped by $15 \%$ in the new building. Another California study of test scores from 21,000 students concluded that students in classrooms with more natural light scored $29 \%$ higher on math tests and $26 \%$ higher on reading tests than students in rooms with less natural light (USGBC, 2003).

\section{INDIRECT BENEFITS}

\section{Healthier to Use}

The use of more natural sources of light, solar energy and more organic materials in a sustainable building, end up with a healthier building than a traditional building. Edward (1998) and USGBC (2003) reported that, the building has been proven to contribute in lower levels of sickness and absenteeism.

\section{Psychological Advantage}

People feel better in a sustainable building. Research in the USA by Edward (1998) claimed that people are not only healthier but they claim an enhance sense of wellbeing. $1 \%$ absenteeism reduction in the building able to pays for the energy costs of a conventional building.

\section{Enhances Company Image}

Sustainable building is normally the result of holistic thinking by a team of professionals, including the client, who share similar sustainable ideas which spread from a company to its buildings, the 
building to the company and the company to the individual thereby enhances its image (Edward, 1998; \& McKee, 1998).

\section{GLOBAL BENEFITS}

The philosophy of sustainable buildings is about considering the whole range of environmental and ecological impacts. Therefore, the design and construction of the building has to consider global warming, ozone layer depletion, biodiversity, product miles and recycling (Edward, 1998; Zainul Abidin, 2009).

Table 1: The successful sustainable building worldwide

\begin{tabular}{|c|c|c|}
\hline Authors & Case Studies & Benefits of Sustainability \\
\hline $\begin{array}{l}\text { Edward } \\
(1998)\end{array}$ & $\begin{array}{l}\text { Student } \\
\text { residences at } \\
\text { Strathclyde } \\
\text { University }\end{array}$ & $\begin{array}{ll}\text { - } & \text { Contented student } \\
\text { - } & \text { The attraction of good quality academic staff } \\
\text { - } & \text { Improved output }\end{array}$ \\
\hline $\begin{array}{l}\text { Francis } \\
(1998)\end{array}$ & $\begin{array}{l}\text { Mixed-use } \\
\text { development- } \\
\text { Sheppard } \\
\text { Robson's Helicon } \\
\text { Building, City of } \\
\text { London }\end{array}$ & $\begin{array}{l}\text { Energy running costs }-£ 50 / \mathrm{m}^{2} \text { per year which is } \\
\text { significantly less than that of conventional office buildings. } \\
\text { Displacement air-conditioning which uses water-filled } \\
\text { panels at ceiling level for cooling - The system costs } 15 \% \\
\text { more, but } 16 \% \text { cheaper to run. }\end{array}$ \\
\hline $\begin{array}{l}\text { Shuttleworth } \\
\text { (1998) }\end{array}$ & $\begin{array}{l}\text { Mistral Building, } \\
\text { Reading }\end{array}$ & $\begin{array}{l}\text { Energy bills about } 20 \% \text { off those of a more conventionally } \\
\text { design office. }\end{array}$ \\
\hline Grut (1998) & $\begin{array}{l}\text { Daimler Benz } \\
\text { Building, Berlin }\end{array}$ & $\begin{array}{l}\text { - Facade cost } 20 \% \text { higher than usual (facade costs are } 9 \% \text { of } \\
\text { total building cost) but help to reduce running cost by } 60 \% \text {, } \\
\text { annual energy consumption predicted as } 75 \mathrm{kWh} / \mathrm{m}^{2} \text { which } \\
\text { is a quarter of that consumed by a typical building office. } \\
\text { - Embodies energy and } \mathrm{CO}_{2} \text { emission } 30 \% \text { less than typical } \\
\text { office building in Berlin. }\end{array}$ \\
\hline $\begin{array}{l}\text { Roy et al } \\
(2005)\end{array}$ & $\begin{array}{l}\text { LEO Building, } \\
\text { Putrajaya, } \\
\text { Malaysia }\end{array}$ & 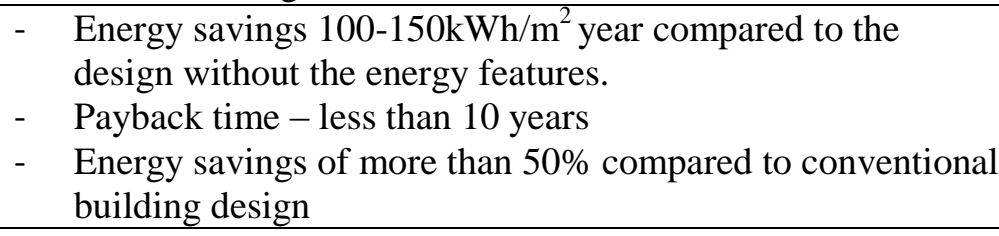 \\
\hline
\end{tabular}

\section{SUSTAINABILITY PRACTICES IN MALAYSIA}

The government of Malaysia has realized the importance of saving the environment through sustainable building development especially toward reducing carbon emission and resources use (Isa et al, 2014; Md Darus et al, 2009; Zainul Abidin, 2009). Many efforts to realize sustainability in building have been implemented in the country. The commitments are including the implementation of photovoltaic systems in buildings through the 'Malaysia Building Integrated Photovoltaic Program' (MBIPV) and introducing renewable energy programme called 'SURIA 1000 for developers'(Zainul Abidin, 2010). The concept of sustainability has also been incorporated in the design of several government office buildings such as LEO (Low Energy Office), GEO (Green Energy Office) and Diamond buildings, which provide a platform for proof of the concept in driving forward the sustainability goals of the Malaysian building industry (Isa et al, 2014). GBI Malaysia has been developed in 2009 for the reason of evaluating the environmental design and performance of Malaysian buildings (GSB, 2012). Sustainability in Malaysian building project is also supported by the numerous current spatial planning of the country such as Malaysian National 
Physical Planning, National Urbanization Policy, Development Plans and the development control activities (GSB, 2012). A special attention is also given in the Tenth Malaysia Plan (2011-2015) towards improving sustainability in the building sector of the country including to the economy plan to harness its energy savings potential and to reduce carbon emissions and dependence on fossil fuel. Revision of the UBBL (Uniform Building Bylaws) to incorporate MS1525 Code of Practice is highlighted in the plan for the integration of renewable energy and energy efficient systems in buildings. Wider adoption of GBI to benchmark energy consumption in the new and existing buildings is also emphasized (APEC, 2012).

Malaysian construction players are always offered a range of different thoughts that point to misconceptions and uncertainty about sustainable development (Dola, 2003). They also claimed to be not fully understood the concept and principles of sustainability (Zainul Abidin, 2009). Besides, it was revealed that the current frameworks of sustainability in the country are not fully equipped to handle sustainable building project (Isa et al, 2014). It is often encouraged environmental measure in most cases, yet the rest of measures are less promoted. Thus, knowledge enhancement and a clear comprehensive framework of sustainable building that considered all aspects of sustainability in building is very crucial to be explored.

\section{METHODOLOGY}

Qualitative analysis technique which is content analysis method was used to analyze and interprets the literatures. Qualitative data analysis techniques lend themselves well to analyzing literature (Onwuegbuzie et al, 2012). Onwuegbuzie et al., (2010) noted that, every selected literature whether representing qualitative, quantitative or mixed research that contains numerous sources of qualitative data such as theoretical framework, author's conclusion and interpretation - thereby, justifying within-case qualitative analyses. Further, when two or more sources are compared and contrasted, then cross-case qualitative analyses are justified. Content analysis technique is one of the various qualitative techniques that can be used to analyses literatures (Onwuegbuzie et al, 2012). Merriam (1998:160) explains that, 'in one sense, all qualitative data analysis is content analysis in that it is the content of interviews, field notes and documents that is analyzed'. The process of content analysis involves simultaneous coding of raw data and the construction of categories that capture relevant characteristics of the document's contents (Merriam, 1998). The crucial step in conducting content analysis for this research is to develop a list of sustainability principles of building that should be considered and integrated into a sustainable building project.

A number of frameworks such as Agenda 21 (1992), The Rio Declaration on Environment and Development (1992), The United Nations Framework on Climate Change (1992) and its Kyoto Protocol (1997), The Millennium Declaration (2000), The Johannesburg Plan of Implementation (2002), Global Reporting Initiative and various BPASs have been reviewed to determine the relevant sustainability principles of building. Kaatz et al (2006) claimed that BPASs assist the delivery of buildings that better suited to their physical settings and that impact positively on their socio-economic and environmental aspects. Reviewing BPASs is useful for more precise understanding on sustainability principles of building to be addressed in developing the framework that is proposed in this study.

Besides, to support the findings and harmonizing them into the contemporary researches; the current studies and practical implementation of sustainability in building projects worldwide were also reviewed. The selection of principles reviewed was based on the indicator framework that addresses all three dimensions of sustainability, the framework has a wide focus at a national, community or company level and it has been proposed at a country level with slight modifications 
of the United Nation's framework. Much has been learnt from the literature review for the study. In its early days, sustainable development was always related to the environmental aspects. Lately, sustainable development specifically in building and construction projects require simultaneous development of four interrelated dimensions - environmental, social, economic and technological (design/innovations/technical) (Abeysundara \& Babel, 2010; Pons \& Aguado, 2012; Reyes et al. 2014; Terio \& Kahkonen, 2011). The four dimensions will be used to be the subheadings of various sustainability principles throughout this research.

\section{FINDINGS AND FORMULATION OF THE THEORETICAL FRAMEWORK}

The findings offered a list of twenty-nine sustainability principles of building to be practiced throughout the whole life of building project. The list of the principles was grouped under four subheadings- environmental, social, economic and design and innovation. The process of grouping of the principles into its own category was quite challenging as many issues do not fall neatly under one sector. For example, the principle of 'urban design, visual and aesthetic' that allocated under 'environmental' category also can be grouped under the category of 'social sustainability' because of the cultural influences that may affect. Due to this reason, the principles were put into categories in which it is considered most important, likely to be mentioned and has most impact. Thus, although the principles were put under certain sectors, it is accepted that other interpretations are possible, as there are conflicts in categorization between published works. But as far as the authors are concerned, these indicators produced intended to put boundaries around the principles although in reality such boundaries do not exist. Details on the sustainability principles of building listed under each category are shown in Table 2. The framework development process and the independent and dependent variables of the study are illustrated in Figure 1 . The variables/principles were then addressed in the formulation of a theoretical framework as portrayed in Figure 2.

Table 2: A review of sustainability principles of building and the supporters

\begin{tabular}{|c|c|}
\hline $\begin{array}{c}\text { Sustainability Principles of } \\
\text { Building }\end{array}$ & Supporters \\
\hline \multicolumn{2}{|c|}{ ENVIRONMENTAL SUSTAINABILITY } \\
\hline $\begin{array}{l}\text { 1. Optimise materials and } \\
\text { resources used }\end{array}$ & $\begin{array}{l}\text { BRE (2013), USGBC (2009), IISBE (2012), GBCA (2008), } \\
\text { GSB (2009), BCA (2012), GRI (2011), DOS (2007), } \\
\text { Schumann (2010), Sayce et al (2004), Graham (2003), Polese } \\
\text { and Stren (2000), Akadiri et al (2012), Zainul Abidin (2009), } \\
\text { Ugwu and Chaupt (2005), Labuschagne et al (2005), Brent and } \\
\text { Labuschagne (2004) }\end{array}$ \\
\hline $\begin{array}{l}\text { 2. Sustainable materials } \\
\text { and resources }\end{array}$ & $\begin{array}{l}\text { BRE (2013), USGBC (2009), IISBE (2012), GBCA (2008), } \\
\text { GSB (2009), BCA (2012), GRI (2011), Schumann (2010), } \\
\text { Zainul Abidin (2010), Sayce et al (2004), Polese and Stren } \\
\text { (2000), Akadiri et al (2012), Zainul Abidin (2009), Gething } \\
\text { and Bordass (2006), Ugwu and Chaupt (2005), Brent and } \\
\text { Labuschagne (2004) }\end{array}$ \\
\hline 3. Energy efficient & $\begin{array}{l}\text { BRE (2013), USGBC (2009), IISBE (2012), GBCA (2008), } \\
\text { GSB (2009), BCA (2012), GRI (2011), DOS (2007), Muldavin } \\
\text { (2010), Zainul Abidin (2010), Sayce et al (2004), Edward } \\
\text { (1998), Akadiri et al (2012), Zainul Abidin (2009), Gething } \\
\text { and Bordass (2006), Labuschagne et al (2005), Brent and } \\
\text { Labuschagne (2004) }\end{array}$ \\
\hline $\begin{array}{l}\text { 4. Efficient water } \\
\text { consumption }\end{array}$ & $\begin{array}{l}\text { BRE (2013), USGBC (2009), IISBE (2012), GBCA (2008), } \\
\text { GSB (2009), BCA (2012), GRI (2011), Schumann (2010), }\end{array}$ \\
\hline
\end{tabular}


Sustainability Principles of Building

Supporters

Zainul Abidin (2010), Sayce et al (2004), Akadiri et al (2012), Zainul Abidin (2009), Gething and Bordass (2006), Ugwu and Chaupt (2005), Labuschagne et al (2005), Brent and Labuschagne (2004)

BRE (2013), IISBE (2012), GBCA (2008), GSB (2009), BCA

5. Noise control (2012), GRI (2011), DOE (2007), Akadiri et al (2012), Zainul Abidin (2009), Gething and Bordass (2006), Ugwu and Chaupt (2005)

6. Urban design, visual IISBE (2012), Zainul Abidin (2010), Akadiri et al (2012), impact and aesthetic Zainul Abidin (2009), Ugwu and Chaupt (2005)

BRE (2013), USGBC (2009), IISBE (2012), GBCA (2008),

7. Site Planning and management GSB (2009), BCA (2012), GRI (2011), DOS (2007), Schumann (2010), Zainul Abidin (2010), Sayce et al (2004), Akadiri et al (2012), Zainul Abidin (2009), Ugwu and Chaupt (2005)

BRE (2013), USGBC (2009), IISBE (2012), GBCA (2008),

8. Transport management GSB (2009), BCA (2012), GRI (2011), Zainul Abidin (2010), Sayce et al (2004), Edward (1998), Gething and Bordass (2006), Ugwu and Chaupt (2005)

BRE (2013), USGBC (2009), IISBE (2012), GBCA (2008),

9. Concern on quality of land, river and sea GSB (2009), BCA (2012), GRI (2011), Schumann (2010), Edward (1998), Akadiri et al (2012), Zainul Abidin (2009), Gething and Bordass (2006), Ugwu and Chaupt (2005), Labuschgne et al (2005), Brent and Labuschagne (2004)

BRE (2013), USGBC (2009), IISBE (2012), GBCA (2008), GSB (2009), BCA (2012), GRI (2011), DOS (2007),

10. Air and emissions quality

Schumann (2010), Zainul Abidin (2010), Edward (1998), Akadiri et al (2012), Zainul Abidin (2009), Ugwu and Chaupt (2005), Labuschagne et al (2005), Brent And Labuschagne (2004)

11. Conserving heritage

IISBE (2012), Sayce et al (2004), Zainul Abidin (2009)

BRE (2013), USGBC (2009), IISBE (2012), GBCA (2008),

12. Efficient environmental management

GSB (2009), BCA (2012), GRI (2011), DOS (2007), Edward (1998), Akadiri et al (2012), Zainul Abidin (2009), Gething and Bordass (2006), Ugwu and Chaupt (2005)

BRE (2013), Akadiri et al (2012), USGBC (2009), IISBE

13. Sustainable method (2012), GSB (2009), BCA (2012), GRI (2011), Sayce et al (2004), Edward (1998), Zainul Abidin (2009), Gething and Bordass (2006), Ugwu and Chaupt (2005)

\section{ECONOMIC SUSTAINABILITY}

14. Economic benefit to the Akadiri et al (2012), IISBE (2012), GRI (2011), Sayce et al stakeholders (2004), Zainul Abidin (2009)

15. Improve local market presence USGBC (2009), GRI (2011), CIDB (2007), Sayce et al., (2004), Edward (1998), Akadiri et al (2012), Ugwu and Chaupt (2005)

BRE (2013), IISBE (2012), DOS (2007), Schumann (2010), Zainul Abidin (2010), Sayce et al (2004), Dixon (2009),

16. Whole life cost efficiency Akadiri et al (2012), Zainul Abidin (2009), Ugwu and Chaupt (2005), Bordass (2000), Edum-Fotwe and Price (2009), Zavrl, M. S., et al, (2009), Essa and Fortune (2008), Lowe 


\begin{tabular}{|c|c|}
\hline $\begin{array}{l}\text { Sustainability Principles of } \\
\text { Building }\end{array}$ & Supporters \\
\hline & and Zhou (2003). \\
\hline 17. Indirect economic impact & $\begin{array}{l}\text { USGBC (2009), GRI (2011), CIDB (2007), Schumann } \\
\text { (2010), Sayce et al (2004), Zainul Abidin (2009), } \\
\text { Labuschagne et al (2005) }\end{array}$ \\
\hline \multicolumn{2}{|l|}{ SOCIAL SUSTAINABILITY } \\
\hline 18. Employment Benefits & $\begin{array}{l}\text { GRI (2011), Ugwu and Chaupt (2005), Zainul Abidin (2010), } \\
\text { Sayce et al (2004), Zainul Abidin (2009), Brent and } \\
\text { Labuschagne (2004) }\end{array}$ \\
\hline $\begin{array}{l}\text { 19. Labor/Management } \\
\text { Relations }\end{array}$ & $\begin{array}{l}\text { GRI (2011), Labuschagne et al., (2005), Navamukundan } \\
\text { (1999) }\end{array}$ \\
\hline $\begin{array}{l}\text { 20. Occupational Health and } \\
\text { Safety }\end{array}$ & $\begin{array}{l}\text { BRE (2013), USGBC (2009), GRI (2011), Schumann (2010), } \\
\text { Zainul Abidin (2010), Sayce et al (2004), Reyes et al (2014), } \\
\text { Zainul Abidin (2009), Ugwu and Chaupt (2005), } \\
\text { Labuschagne et al (2005), Brent and Labuschagne (2004), } \\
\text { Lombardi (2001), Parkin, (2000) }\end{array}$ \\
\hline $\begin{array}{l}\text { 21. Training, Education and } \\
\text { Awareness }\end{array}$ & $\begin{array}{l}\text { BRE (2013), GRI (2011), CIDB (2007), Edward (1998), } \\
\text { Reyes et al., (2014), Gething and Bordass (2006), } \\
\text { Labuschgne et al., (2005) }\end{array}$ \\
\hline 22. Fairness & $\begin{array}{l}\text { GRI (2011), Sayce et al (2004), Haris and Goodwin (2001), } \\
\text { Polese and Stren (2000), Edward (1998), Labuschagne et al } \\
\text { (2005), Brent and Labuschagne (2004) }\end{array}$ \\
\hline 23. Human right performance & $\begin{array}{l}\text { GRI (2011), Ugwu and Chaupt (2005), Brent and } \\
\text { Labuschagne (2004) }\end{array}$ \\
\hline 24. Society Performance & IISBE (2012), GRI (2011) \\
\hline 25. Product responsibility & $\begin{array}{l}\text { BRE (2013), USGBC (2009), IISBE (2012), GSB (2009), } \\
\text { GRI (2011), CIDB (2006), Schumann (2010), ASHRAE } \\
\text { (2006), Sayce et al (2004), Edward (1998), Reyes et al } \\
\text { (2014), Akadiri et al (2012), Gething and Bordass (2006) }\end{array}$ \\
\hline $\begin{array}{l}\text { 26. Stakeholders } \\
\text { participation }\end{array}$ & $\begin{array}{l}\text { BRE (2013), Akadiri et al (2012), IISBE (2012), Yudelson } \\
\text { (2009), Magis and Shinn (2009), ASHRAE (2006), Sayce et } \\
\text { al (2004), Labuschagne et al (2005), Brent and Labuschagne } \\
\text { (2004), Taylor (2003) }\end{array}$ \\
\hline $\begin{array}{l}\text { 27. Macro social } \\
\text { performance }\end{array}$ & $\begin{array}{l}\text { Zainul Abidin (2009), Labuschagne et al (2005), Brent and } \\
\text { Labuschagne (2004) }\end{array}$ \\
\hline \multicolumn{2}{|l|}{$\begin{array}{l}\text { DESIGN AND } \\
\text { INNOVATION }\end{array}$} \\
\hline 28. Sustainable Design & $\begin{array}{l}\text { BRE (2013), Akadiri et al (2012), USGBC (2009), IISBE } \\
\text { (2012), GBCA (2008), GSB (2009), BCA (2012), DOS } \\
\text { (2007), Muldavin (2010), Zainul Abidin (2010), Sayce et al } \\
\text { (2004), Edward (1998), Reyes et al (2014), Zainul Abidin } \\
\text { (2009), Gething and Bordass (2006) }\end{array}$ \\
\hline 29. Sustainable Innovation & $\begin{array}{l}\text { BRE (2013), USGBC (2009), GBCA (2008), GSB (2009), } \\
\text { BCA (2012), Edward (1998), Reyes et al (2014), Ugwu and } \\
\text { Chaupt (2005) }\end{array}$ \\
\hline
\end{tabular}




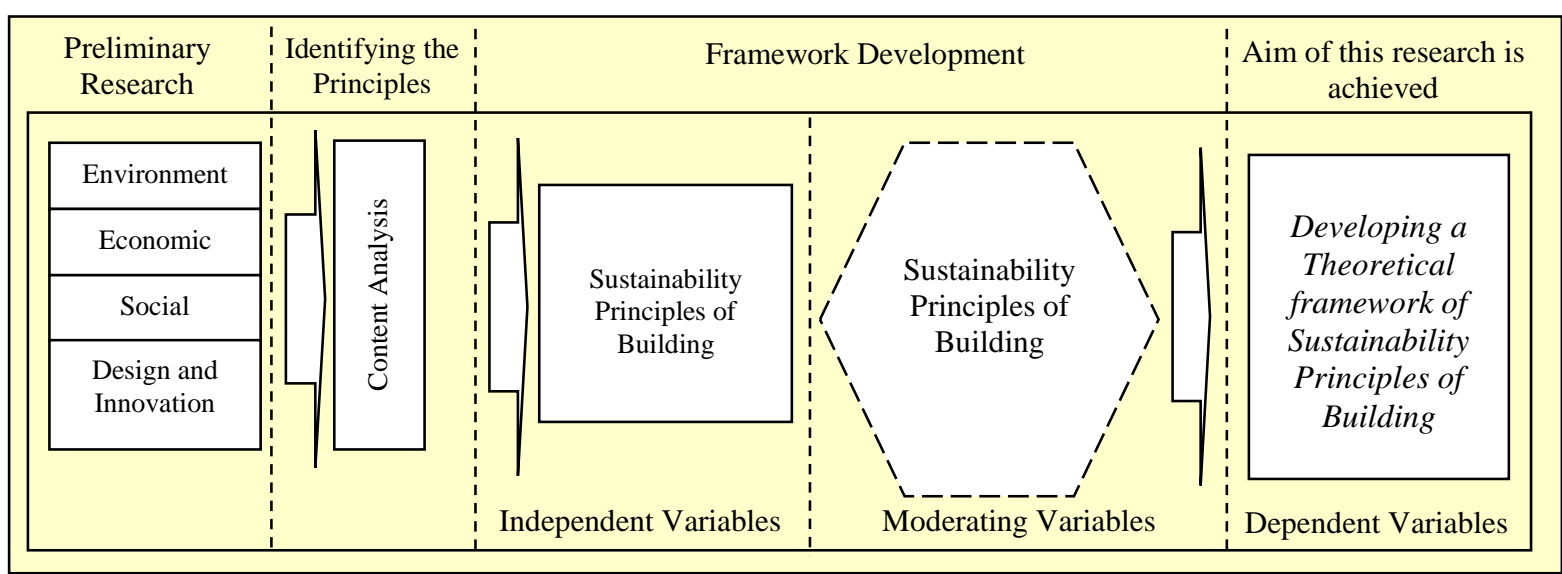

Figure 1: The research model for developing the theoretical framework of sustainability principles of building

The brief checklist as developed in Table 2 allows the right mix of sustainable development principles to be established. In conclusion, sustainable building is a project that performs as a sustainable product, sustainable in application and is constructed in a sustainable manner. Sustainable building also should consider the integration of environment, social, economic in their innovative design into the building whole life as illustrated in the theoretical framework (Figure 2). It should be stressed that the life cycle analysis of a building needs to be carried out in determining whether or not the building is categorized as a sustainable or otherwise.

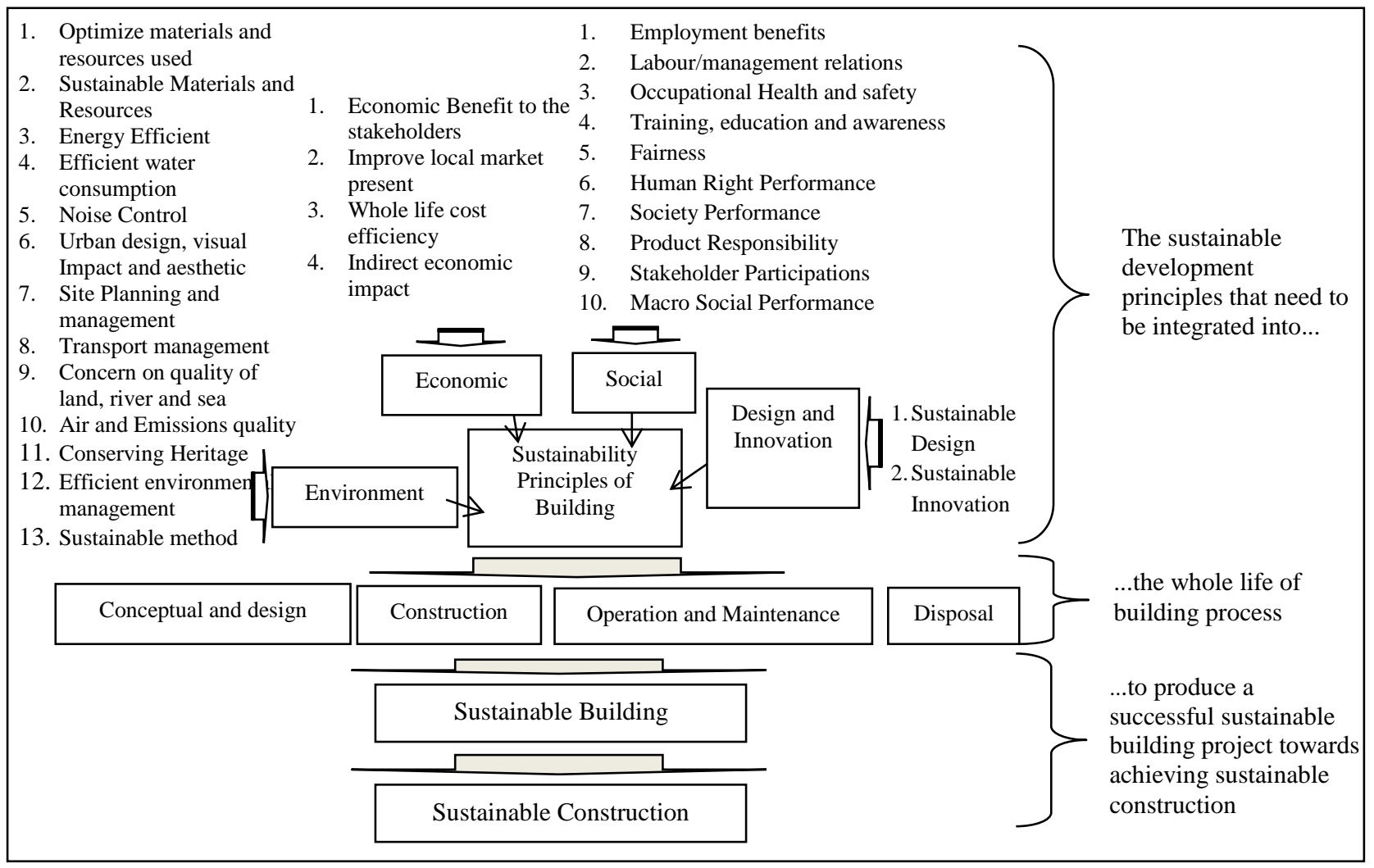

Figure 2: A theoretical framework of sustainability principles of building 


\section{CONCLUSION}

Sustainable buildings are naturally different from conventional buildings. They require special materials and building practices as well as management commitment to sustainability. Research in this area could provide a clear picture for integrating and practicing sustainability throughout the whole life of building projects. The unique characteristics of sustainable building project required adjustments to the conventional project management practices to minimize risks and improve the chances of delivering the project within acceptable costs and schedule. In turn, this research sought to formulate a theoretical framework of sustainability principles of building to be integrated through the whole life of the building.

The framework was developed by taking into account the environment, social, economic and design and innovation aspects to be measured throughout the building project, process and product life cycle. The theoretical framework is very useful to provide an essential guide to the project stakeholders and researchers especially for formulating a clear guide of sustainability principles to be integrated into the development of future sustainable building projects in Malaysia. For further studies, it is interesting to investigate in depth the proposed sustainability principles of building for their possibility to be practiced in the country. It is also crucial to explore the strategies to integrate the principles efficiently into the building project especially through the planning process of the project.

\section{REFERENCES}

Abeysundara, U., \& Babel, S. (2010). A quest for sustainable materials for building elements in Sri Lanka: Foundations. Environmental Progress and Sustainable Energy, 29(3), 370-381.

Adler, A., Amstrong, J. E., Fuller, S., Kallin, M., Karolides, A., Macaluso, J., et al. (2006). Green building: Project planning and cost estimating (2nd ed.). Kingston: R.S Means.

Akadiri, P. O., Chinyio, E. A., \& Olomolaiye, P. O. (2012). Design of a sustainable building: A conceptual framework for implemanting sustainability in the building sector. Buildings, 2, $126-152$.

APEC. (2012). APEC Energy Overview 2012. Retrieved 12th September, 2013, from http://publications.apec.org/publication-detail.php?pub_id=1432

ASHRAE. (2006). ASHRAE Green Guide: The design, construction and operation of sustainable buildings (2nd ed.). Atlanta: American Society of Heating Refrigerating and Air Conditioning Engineers. Inc.

BCA. (2012). BCA Green Mark: Certification standard for new buildings (GM Version 4.1). Retrieved 18th July 2013, from http://www.bca.gov.sg/EnvSusLegislation/others/ GM_Certification_Std2012.pdf

Beatley, N. (2008). Pathways to green building and sustainable design: A policy primer for funders, funders' network for smart growth and liveable communities. from http://www.fundersnetwork.org/files/learn/Pathways_to_Green_Building_-_Policy_Primer_ 081112.pdf

Bordass, B. (2000). Cost and value: fact and fiction. Building Research and Information, 28(5/6), 338-352.

BRE. (2013). BREEAM international new construction technical manual. Retrieved 15th July, 2013, from http://www.breeam.org/BREEAMInt2013SchemeDocument/ 
Brent, A. C., \& Labuschange, C. (2004, 18-21 October). Sustainable life cycle management: Indicators to assess the sustainability of engineering projects and technologies. Paper presented at the Engineering Management Conference, 2004.

CBRE (2009). Who pays for green? The economics of sustainable buildings. EMEA Research. CB Richard Ellis

Chaharbaghi, K., \& Wilis, R. (1999). The study and practice of sustainable development. Engineering Management Journal, 9(1), 41-48.

Choi, C. (2009). Removing market barriers to green development: principles and action projects to promote widespread adoption of green development practices. JOSRE, 1(1), 107-138.

CIDB. (2006). Quality assessment system for building construction work- construction industry standard CIS 7:2006. Kuala Lumpur: Construction Industry Development Board,.

CIDB. (2007). Construction industry master plan Malaysia 2006-2015, Malaysia: CIDB.

Cole, R. J. (2006). Shared market: Coexisting building environmental assessment methods. Building Research and Information, 34(4), 357-371.

DETR (2000). Building a better quality of life: A strategy for more sustainable construction. London. Retrieved September 2, 2010, from http://www.berr.gov.uk/files/file13547.pdf.

Dixon, T. (2009). RICS green gauge 2008/09: RICS members and the sustainability agenda. Oxford: Oxford Institute for Sustainable Development, Oxford Brookes University.

Dola, K. (2003). Incorporating sustainable development principles into the local plan preparation process: The case of selected localities in southern region of Peninsular Malaysia. Unpublished $\mathrm{PhD}$ Thesis, Universiti Teknologi Malaysia.

DOE (2007) The planning guidelines for environmental noise limits and control (2nd ed.) Putrajaya, Department of Environment Malaysia

DOS (2007). MS1525: Code of practice on energy efficiency and use of renewable energy for nonresidential buildings. Kuala Lumpur, Malaysia: SIRIM Berhad.

Doyle, J. T., Brown, R. B., De Leon, D. P., \& Ludwig, L. (2009). Building green-potential impacts to the project schedule. International Transactions, PS.08.01-PS.08.11.

Du Plesis, C. (2005). Action for sustainability: Preparing an african plan for sustainable building and construction. Building Research and Information, 33(5), 404-415.

Edum-Fotwe, F. T., \& Price, A. D. F. (2009). A social ontology for appraising sustainability of construction projects and development. International Journal of Project Management, 27(4), 313-322.

Edward, B. (1998). Green buildings Pay. Oxford: Alden Press.

Essa, R., \& Fortune, C. (2008). Pre-construction evaluation practices of sustainable housing projects in the UK. Engineering Construction and Architectural Management, 16(6), 514-526.

Francis, G. (1998). The relevance of green buildings to the procurement and marketability of office. In E. B (Ed.), Green Buildings Pay. Oxford: Elden Press.

GBCA. (2008). Green star - Office v3 technical manual. Retrieved 17th July, 2013, from http://www.gbca.org.au/green-star/rating-tools/green-star-office-v3/1710.htm

Gething, B., \& Bordass, B. (2006). Rapid asessment checklist for sustainable buildings. Building Research and Information, 34(4), 416-426

Graham, P. (2003). Building Ecology-First Principles for a Sustainable Built Environment Oxford, UK: Blackwell Publishing.

Grevelman, L., \& Kluiwstra, M. (2010). Sustainability in project management: A case study on enexis. PM World Today, 12(7).

GRI. (2011). Sustainability reporting guidelines (G3.1 Guidelines 2000-2011). Retrieved 3rd February, 2012, from https://www.globalreporting.org/reporting/G3andG3-1/Pages/default. aspx

Grut, L. (1998). Daimler benz building, Berlin. In E. B (Ed.), Green Buildings Pay. Oxford: Elden Press. 
GSB. (2009). GBI assessment criteria for non-residential new construction (NRNC). Retrieved 19th July, 2011, from http://www.greenbuildingindex.org/Resources/GBI\%20Tools/ GBI\%20NRNC\%20Non-Residential\%20Tool\%20V1.0.pdf.

GSB. (2012). What is a green building. Retrieved 4th November, 2012, from http://www.greenbuildingindex.org/why-green-buildings.html

Harris, J. M., \& Goodwin, N. R. (2001). Volume Introduction. In J. M. Harris, T. A. Wise, K. P. Gallagher \& N. R. Goodwin (Eds.), A survey of sustainable development: Social and economic dimensions Washington DC: Island Press.

Hill, R. C., \& Bowen, P. A. (1997). Sustainable construction: Principles and a framework for attainment. Construction Management and Economics, 15, 23-239.

IISBE. (2012). SBTool 2012. Retrieved 17th July, 2013, from http://www.iisbe.org/sbtool-2012

Isa, N.K.M, Alias, A., \& Abdul Samad, Z. (2014). Sustainability integration into building projects: Malaysian construction stakeholders' perspectives. The Macrotheme Review, 3(3), 14-34.

Kaatz, E., Root, D., \& Bowen, P. (2005). Broadening project participation through a modified building sustainability assessment. Building Research and Information, 33(5), 441-454.

Kaatz, E., Root, D., Bowen, P., \& Hill, R. C. (2006). Advancing key outcomes of sustainability building assessment. Building Research and Information, 34(4), 308-320.

Kibert, C. J. (2005). Sustainable construction: Green building design and delivery. Hoboken, N.J: Wiley.

Labuschagne, C., Brent, A., \& Claasen, S. J. (2005). Environmental and social impact considerations for sustainable project life cycle management in the process industry. Corporate Social Responsibility and Environmental Management, 12, 38-54.

Larsen, G. L. (2009). An inquiry into the theoretical basis of sustainability, ten propositions. In J. Dillard, V. Dujon \& M. C. King (Eds.), Understanding the social dimension of sustainability. New York: Routledge.

Lombardi, P. L. (2001). Responsibilities toward the coming generations: forming a new creed. Urban Design Studies, 7, 89-102.

Lowe, D. J., \& Zhou, L. (2003, 1st-2nd September). Economic challenges of sustainable construction. Paper presented at the RICS COBRA Foundation Construction and Building Research Conference, University of Wolverhampton.

Lutzkendorf, T., \& Lorenz, D. (2006). Using and integrated performance approach in building assessment tools. Building Research and Information, 34(4), 334-356.

Magis, K., \& Shinn, C. (2009). Emergent principles of social sustainability. In J. Dillard, V. Dujon \& M. C. King (Eds.), Understanding the social dimension of sustainability. New York: Routledge.

McKee, W. (1998). Green buildings and the UK property industry. In B. Edward (Ed.), Green Buildings Pay. Oxford: Elden Press.

Md Darus, Z., Hashim, N. A., Salleh, E., Haw, L. C., Abdul Rashid, A. K., \& Abdul Manan, S. N. (2009). Development of rating system for sustainable building in Malaysia. WSEAS Transactions on Environment and Development, 5(3), 260-272.

Merriam, S. (1998). Qualitative research and case study applications in education. California: Jossey-Bass Publisher.

Muldavin, S. R. (2010). Value beyond cost savings, how to underwrite sustainable properties. USA: Muldavin Company Inc.

Navamukundan, A. (1999). The true challenge: To bring about equitable and meaningful income distribution in society. In International Labour Organization (ILO) (Ed.), Collective bargaining: A fundamental principle, a right, a Convention: Labour Education 1999/1-2 Nos. 114-115. Geneva: ILO.

Onwuegbuzie, A. J., Collins, K. M. T., Leech, N. L., Dellinger, A. B., \& Jiao, Q. G. (2010). A meta-framework for conducting mixed research syntheses for stress and coping researchers 
and beyond. In G. S. Gates, W. H. Gmelch, \& M. Wolverton (Series Eds.) \& K. M. T. Collins, A. J. Onwuegbuzie, \& Q. G. Jiao (Vol. Eds.), Toward a broader understanding of stress and coping: Mixed methods approaches (169-211). The research on stress and coping in education series (vol.5). Charlotte, NC: Information Age.

Onwuegbuzie, A. J., Leech, N. L., \& Collins, K. M. T. (2012). Qualitative analysis techniques for the review of the literature. The Qualitative Report, 17(56), 1-28.

Parkin, S., (2000) Sustainable development: The concept and the practical challenge, proceedings of the Institution of Civil Engineers: Civil Engineering, vol. 138(6) pp. 3-8. Retrieved 1st September 2010, from http://www.icevirtuallibrary.com/content/article/10.1680/cien.2000. 138.6.3

Polese, M., \& Stren, R. (2000). The social sustainability of cities: Diversity and the management of change. Toronto: University of Toronto Press.

Pons, O., \& Aguado, A. (2012). Integrated value model for sustainable assessment applied to technologies used to build schools in Catalonia, Spain. Building and Environment (53), 59-58.

Popea, J., Annandale, D., \& Morrison-Saunders, A. (2004). Conceptualising sustainability assessment. Environmental Impact Assessment Review, 24(6), 595-616.

Reyes, J. P., San-Jose, J. T., Cuadrado, J., \& Sancibrian, R. (2014). Health and safety criteria for determining the sustainable value of construction projects Safety Science, 62, 221-232.

Roy, A. K., Mahmood, A. R., Balslev-Olesen, O., Lojuntin, S., \& Tang, C. (2005). Low energy office building in Putrajaya, Malaysia: Case Studies and Innovations. Paper presented at The 2005 World Sustainable Building Conference. Retrieved 1st December 2011, from www.irbnet.de/daten/iconda/CIYUDELSON (2009)371.pdf

Sayce, S., Walker, A., \& McIntosh, A. (2004). Building sustainability in the balance: Promoting stakeholder dialogue. London: Estate Gazette.

Schumann, B. (2010). Impact of sustainability on property value. Master's Thesis, Regensburg: University of Regensburg.

Shuttleworth, K. (1998). Mistral building reading. In E. B (Ed.). Oxford: Elden Press.

Taylor, S. (2003, 10 Feb. 2003). The human resource side of sustainability, Presentation at Portland State University.

Terio, O., \& Kahkonen, K. (2011). Developing and implementing environmental management systems for small and medium-sized construction enterprises. Construction Management and Economics, 29(12), 1183-1195.

The Economist. (2004). The rise of green building. The Economist, 373, Special section 17-23.

Todd, J. A., Crawley, D., Geissler, S., \& Lindsey, G. (2001). Comparative assessment of environmental performance tools and the role of the green building challenge. Building Research and Information, 29(5), 324-335.

Ugwu, O. O., \& Chaupt, T. (2005). Key performance indicators for infrastructure sustainability - a comparative study between Hong Kong and South Africa. Journal of Engineering, Design and Technology, 3(1), 30-43.

USGBC. (2003). Building momentum: National trends and prospects for high-performance green buildings: A report prepared for the U.S Senate Committee on environment and public works. Retrieved 1st August, 2010, from http://www.usgbc.org/Docs/Resources/043003_hpgb_ whitepaper.pdf

USGBC (2006a). Building a greener future. Special advertising section in partnership with Fortune. Fortune, March 20, S2-S14. Retrieved 1st August 2010, from http://www.usgbc.org

USGBC. (2006b). Project profile: Fossil Ridge High School. Fort Collins, Colorado. USGBC 2006 Case Studies. Retrieved 1st August 2010 from http://www.usgbc.org/ DisplayPage.aspx?CMSPageID $=75 \&$ 
USGBC. (2009). LEED 2009 for new construction and major renovations. Retrieved 16 July 2013, from http://www.usgbc.org/sites/default/files/LEED\%202009\%20RS_NC_04.01.13 current. pdf

WCED. (1987). Our common future. Oxford United Kingdom: Oxford University Press.

$\mathrm{Wu}$, P.; \& Low, S.P. (2010). Project management and green buildings: Lesson from the rating systems. Journal of Professional Issues in Engineering Education and Practice, 136(2), 6467.

Yudelson, J. (2009). Green building through integrated design. United States: Mc Graw Hill Companies.

Zainul Abidin, N. (2009). Sustainable construction in Malaysia - Developers' awareness, World Academy of Science, Engineering and Technology 53, 807-814.

Zainul Abidin, N. (2010). Environmental concerns in Malaysian construction industry. Pulau Pinang, Malaysia: Universiti Sains Malaysia.

Zavrl, M. S., Zarnic, R., \& Selih, J. (2009). multicriteria sustainability assessment of residential buildings. Technological and Economic Development of Economic, 15(4), 612-630. 